\title{
Effects of heavy metals on soil microbial biomass carbon
}

\begin{abstract}
This study was aimed at evaluating the effect of heavy metals on soil microbial processes. The effects of Lead $(\mathrm{Pb})$ and Cadmium $(\mathrm{Cd})$ at different concentrations were investigated over a period of eight weeks. Chloride salts of $\mathrm{Pb}$ and $\mathrm{Cd}$ were added singly and in combination to soil samples at room temperature (270C) in different polythene bags. Samples were taken from the bags at two weeks interval and measurements were taken of the microbial biomass carbon (MBC). The results showed that there was a significant decrease in the microbial biomass carbon for all treated soils from the second week to the sixth week. But there was an observed increase in microbial biomass carbon on the eight week. At the sixth week, 2000mgkg- $1 \mathrm{~Pb}$ and $40 \mathrm{mgkg}-1 \mathrm{Cd}$ gave the most significant decrease $(\mathrm{P}<0.05)$ in microbial biomass carbon of $98 \%$
\end{abstract}

Volume 4 Issue I - 2019

\author{
Oijagbe IJ,' Abubakar BY,' Edogbanya PRO,' \\ Suleiman $\mathrm{MO}^{2}$ OlorunmolaJB ${ }^{2}$ \\ 'Department of Biology, Ahmadu Bello University, Nigeria \\ ${ }^{2}$ Department of Plant Science and Biotechnology, Kogi State \\ University, Nigeria
}

\begin{abstract}
Correspondence: Oijagbe IJ, Department of Biology,Ahmadu Bello University, Zaria, Nigeria, Tel +23480364I58I4,
\end{abstract} Email joijagbe@gmail.com

Received: January 23, 2019 | Published: February 28, 2019

Keywords: accumulation, mineralization, microbial biomass carbon, heavy metals

\section{Introduction}

Heavy metals are naturally occurring elements that have a high atomic weight and a density at least five times greater than that of water. ${ }^{1,2}$

Some debate exists as to exactly what constitutes a "heavy metal" and which elements should properly be classified as such. Some authors have based the definition on atomic weight, while others point to those metals with a specific gravity of greater than 4.0, or greater than 5.0. Most recently, the term "heavy metal" has been used as a general term for those metals and semimetals with potential human or environmental toxicity. ${ }^{2,3}$ Metal distribution between soil and vegetation is a key issue in assessing environmental effect of metals in the environment. ${ }^{4}$

Heavy metal toxicity to plants vary with plant species, specific metal, concentration, chemical form, and soil composition and $\mathrm{pH}$, as many heavy metals are considered to be essential for plant growth and similarly, many heavy metals are essential trace nutrients of animals and human body ${ }^{5}$ Some of these heavy metals like $\mathrm{Cu}$ and $\mathrm{Zn}$ serve either as cofactor and activators of enzyme reactions e.g. informing enzymes/substrate metal complex ${ }^{6}$ or exert a catalytic property such as prosthetic group in metalloproteins. These essential trace metal nutrients take part in redox reactions, electron transfer and structural functions in nucleic acid metabolism. Some heavy metal such as $\mathrm{Cd}$, $\mathrm{Hg}$ and As, etc are strongly poisonous to metal sensitive enzymes, resulting in growth inhibition and death of organisms. ${ }^{7}$ Most plants depend on soil and plants and their associated microorganisms also play a crucial role in the formation or modification of soil. ${ }^{8}$

Soil Carbon is predominantly derived from plants, directly or indirectly, and whilst weathering may be due to physical and chemical influences, most weathering processes involve plants, primarily roots, or microbial activities that depend on root-derived Carbon. ${ }^{9}$ Some microorganisms in the soil are responsible for nitrogen fixation, assimilation and degradation of organic residues to release nutrients. ${ }^{10,11}$

Heavy metal toxicity has an inhibitory effect on plant growth, enzymatic activity, stoma function, photosynthesis activity and accumulation of other nutrient elements and also damages the root system. To the concern of the soil however, the effects of heavy metals pollutants could be enormous. Major amongst which is their effects on microbial activities. ${ }^{12}$

Restrictions placed on the levels of accumulation of heavy metals in agricultural soils are based on known effects of heavy metals on plant uptake and animal health but takes no account of the effects on soil microorganisms or important microbial processes like carbon and nitrogen mineralization, microbial biomass carbon and nitrogen and respiration. ${ }^{13}$ Hence, there is need to evaluate the effects of these heavy metals at varying concentration on soil microorganisms as it will further provide valid information for determining restrictions limits.

In this work, the effects of Lead $(\mathrm{Pb})$ and Cadmium $(\mathrm{Cd})$ at varied concentrations on soil microbial processes were studied singly and in combination. The microbial biomass and the rates of nitrogen and carbon mineralization were monitored.

\section{Materials and methods}

Soil samples were collected from the Botanical Garden of the Department of Biological Sciences, Ahmadu Bello University, Samaru Main Campus, Zaria (Lat $11^{\circ} 11^{\prime} \mathrm{N}$; Long $7^{\circ} 38^{\prime} \mathrm{N}$; Altitude $660 \mathrm{~m}$ above sea level). It is about $4188604 \mathrm{~m}^{2}$ (4.2hectares) and segmented into 19 plots. It is a relatively undisturbed site with no farming and grazing activities and located in guinea savannah zone of Nigeria with distinct dry and rainy season. ${ }^{14,15}$ However, for this study, the garden was divided into two sections; the area dominated by trees and grasses. All soil samples collected from the sampling points were pooled together to obtain a homogenous unity sample. The soil samples were stored in plastic bags and transported to the Department of Biological Sciences. Soil heavy metal content was analyzed using the Atomic Absorption Spectrophotometer (Shimazu AAS, model AA-6800) at NARICT, Basawa, Zaria. Other soil analyses were done at the Institute of Agricultural Research (IAR), Samaru, Zaria. Soil pH was measured in 1:2 soil to water ratio using $\mathrm{pH}$ meter (PHS-3C). Soil organic matter $(\mathrm{OM})$ was determined by wet oxidation methods as described by Walkley and Black (1934). ${ }^{16}$ Soil particles analysis was done using hydrometer method as described by Bouyoucos. ${ }^{17}$

Microbial biomass carbon was determined by the fumigation extraction method. ${ }^{18}$ Soil samples were sieved using $2 \mathrm{~mm}$ sieve to remove dirt. Sieved soil samples $(1 \mathrm{~kg})$ were distributed into eighteen 
(18) $25 \mathrm{~cm}$ diameter polythene pots labeled appropriately. Soil samples in the pots were mixed with salts solutions of $\mathrm{Cd}$ as Cadmium Chloride $\mathrm{CdCl}_{2}$ (20mg and 40mg), $\mathrm{Pb}$ as Lead Chloride $\mathrm{PbCl}_{2}$ (1000mg and $2000 \mathrm{mg}$ ) separately and in combination. The soil sample with no heavy metal amendment was used as control. All the analyses were done in triplicates. The results were analyzed by two-way analysis of variance (ANOVA) at $95 \%$ confidence interval. Duncan multiple range test (DMRT) was used to separate means where significant ( $\mathrm{P}$ $<0.05)$.

\section{Results and discussion}

Table 1 shows the characteristics of the soil used. The results show that the soil is slightly acidic with a $\mathrm{pH}$ value of 6.10 and could be texturally classified as loamy soil with $14 \%$ (clay), $49 \%$ (silt) and $37 \%$ (sand). Table 2 shows the patterns of heavy metal amendment (addition) in pre-incubated soil pots, with concentrations of Lead $1000 \mathrm{mgkg}^{-1}(\mathrm{~Pb} 1), \quad 2000 \mathrm{mgkg}^{-1}(\mathrm{~Pb} 2)$, Cadmium $20 \mathrm{mgkg}^{-1}(\mathrm{Cd} 1)$, $40 \mathrm{mgkg}^{-1}(\mathrm{Cd} 2)$ and a combination of $1000 \mathrm{mgkg}^{-1} \mathrm{~Pb}$ and $20 \mathrm{mgkg}^{-1} \mathrm{Cd}$. While Table 1 also shows the heavy metal profile of the soil prior to amendment as determined by Atomic Absorption Spectrophotometry (AAS), indicating the presence of $\mathrm{Cd}$ at a very low or insignificant level (0.000071) and $\mathrm{Pb}$ to be undetected (absent).

The results on Table 3 showed a significant decline in biomass carbon among the treatments across the weeks. At the beginning of the experiment, there was a general decrease in biomass carbon, but at the eight week there was an increase. Among the treatments, the highest mean value $(1296 \mu \mathrm{g} / \mathrm{g})$ was obtained in $\mathrm{Cd} 1$ treated soil while the least mean value $(654 \mu \mathrm{g} / \mathrm{g})$ was in $\mathrm{Pb} 2$ treated soil. But across the weeks, week 0 had the highest mean value $(2487.50 \mu \mathrm{g} / \mathrm{g})$ and week 6 had the least mean value $(400 \mu \mathrm{g} / \mathrm{g})$.
Table I Characteristics of the soil

\begin{tabular}{ll}
\hline Parameters & Results \\
\hline $\mathrm{pH}\left(\mathrm{H}_{2} \mathrm{O}\right)$ & 6.10 \\
Organic carbon $(\%)$ & 1.56 \\
Total nitrogen (\%) & 0.195 \\
Soil organic matter $(\%)$ & 2.69 \\
Clay $(\%)$ & 14 \\
Silt $(\%)$ & 49 \\
Sand $(\%)$ & 37 \\
Textural class (U.S.D.A) & LOAM \\
Pb(mg/kg) & ND (NOT DETECTED) \\
$\mathrm{Cd}(\mathrm{mg} / \mathrm{kg})$ & 0.000071
\end{tabular}

Table 2 Pattern of metal amendment in pre-incubated soil pots

\begin{tabular}{lll}
\hline Sample & Treatment & Concentration $(\mathrm{mg} / \mathrm{kg})$ \\
\hline $\mathrm{CT}$ & CONTROL & - \\
$\mathrm{L} 1$ & $\mathrm{~Pb} 1$ & 1000 \\
$\mathrm{~L} 2$ & $\mathrm{~Pb} 2$ & 2000 \\
$\mathrm{C} 1$ & $\mathrm{Cd} 1$ & 20 \\
$\mathrm{C} 2$ & $\mathrm{Cd} 2$ & 40 \\
$\mathrm{~L} 1 \mathrm{C} 1$ & $\mathrm{~Pb} 1: \mathrm{Cd} 1$ & $1000: 20$
\end{tabular}

Pollution of soil by heavy metals do not only result in adverse effects on various parameters that have to do with plant quality and yield, but also causes changes in the composition and activity of soil microorganisms. ${ }^{19,20}$ Microbial biomass carbon and nitrogen is a standard technique use to determine the effects of heavy metals on soil microorganisms..$^{21,22}$

Table 3 Mean Soil Biomass Carbon for different treatments of $\mathrm{Cd}$ and $\mathrm{Pb}$ for eight weeks $(\mu \mathrm{g} / \mathrm{g})$

\begin{tabular}{|c|c|c|c|c|c|c|}
\hline \multirow{2}{*}{ Treatment } & \multicolumn{5}{|c|}{ BIOMASS CARBON (ug/g) } & \multirow[b]{2}{*}{ Mean total } \\
\hline & Week 0 & Week 2 & Week 4 & Week 6 & Week 8 & \\
\hline Control & $2500.00 \pm 1.15^{\mathrm{A}, \mathrm{a}}$ & $2470.00 \pm 0.58^{\mathrm{A}, \mathrm{b}}$ & $2050.00 \pm 0.58^{A, C}$ & $1800.00 \pm 0.58^{A, e}$ & $2000.00 \pm 0.06^{\mathrm{A}, \mathrm{d}}$ & $2164 \pm 203.33^{A}$ \\
\hline $\mathrm{Pb} \mathrm{l}$ & $2495.00 \pm 0.58^{\mathrm{B}, \mathrm{a}}$ & $360.00 \pm 0.12^{D, c}$ & $180.00 \pm 0.06^{\mathrm{B}, \mathrm{b}}$ & $|60.00 \pm 0.0|^{\mathrm{C}, \mathrm{a}}$ & $600.00 \pm 0.06^{\mathrm{D}, \mathrm{b}}$ & $759.00 \pm 235.80^{\mathrm{E}}$ \\
\hline $\mathrm{Pb} 2$ & $2490.00 \pm 0.58^{\mathrm{C}, \mathrm{a}}$ & $240.00 \pm 0.06^{\mathrm{E}, \mathrm{c}}$ & $60.00 \pm 0.00^{\mathrm{D}, \mathrm{d}}$ & $60.00 \pm 0.10^{E, d}$ & $420.00 \pm 0.06^{\mathrm{Fb}}$ & $654.00 \pm 247.93^{F}$ \\
\hline Cd I & $2480.00 \pm 0.58^{\mathrm{D}, \mathrm{a}}$ & $2400.00 \pm 0.58^{\mathrm{B}, \mathrm{b}}$ & $160.00 \pm 0.06^{\mathrm{C}, \mathrm{e}}$ & $240.00 \pm 0.5 I^{B, d}$ & $1200.00 \pm 0.58^{\mathrm{B}, \mathrm{c}}$ & $1296.00 \pm 268.20^{B}$ \\
\hline Cd 2 & $2480.00 \pm 0.58^{\mathrm{D}, \mathrm{a}}$ & $2000.00 \pm 1.15^{\mathrm{C}, \mathrm{b}}$ & $60.00 \pm 0.00^{\mathrm{D}, \mathrm{d}}$ & $60.00 \pm\left. 0.0\right|^{E, d}$ & $480.00 \pm 0.06^{\mathrm{E}, \mathrm{c}}$ & $1016.00 \pm 273.25^{c}$ \\
\hline $\mathrm{Pb}: \mathrm{Cd}$ & $2480.00 \pm I .58^{\mathrm{D}, \mathrm{a}}$ & $360.00 \pm 0.06^{\mathrm{D}, \mathrm{c}}$ & $180.00 \pm 0.06^{\mathrm{B}, \mathrm{d}}$ & $80.00 \pm 0.00^{\mathrm{D}, \mathrm{e}}$ & $1000.00 \pm 2.00^{\mathrm{c}, \mathrm{b}}$ & $820.00 \pm 248.5 I^{D}$ \\
\hline Overall & $2487.50 \pm 1.97^{\mathrm{a}}$ & $\left.|305.67 \pm 24| .7\right|^{b}$ & $448.33 \pm 174.16^{d}$ & $400.00 \pm 152.65^{e}$ & $950.00 \pm 82.8 I^{c}$ & $1086.90 \pm 0.112$ \\
\hline
\end{tabular}

Mean \pm S.E; $n=3$; Values with the same UPPERCASED superscript down a column (except overall) are not significantly different (P>0.05); Values with the same lowercased superscript across a row (except overall) are not significantly different difference $(P>0.05)$.

There was a general inhibition of microbial biomass carbon after application of heavy metals. Both heavy metals (cadmium and lead) at their various concentrations and combination showed a negative effect on the microbial biomass as shown in Table 3.

The results show that the least measurements were obtained from $\mathrm{Pb} 2\left(2000 \mathrm{mgkg}^{-1}\right)$ and $\mathrm{Cd} 2\left(40 \mathrm{mgkg}^{-1}\right)$ at week six of the experiment. This is in line with the result obtained by Akmal et al., ${ }^{20}$ which reported a significant decrease in microbial biomass carbon within four weeks of his experiment with regards to the use of $\mathrm{Pb}$ and $\mathrm{Cd}$. Sethi and Gupta $^{22}$ also reported a similar decrease in soil microbial biomass with the use of $\mathrm{Cd}$ as the pollutant and that this may be as a result of the change in microbial community structure affected by heavy metals. This observed decrease in microbial biomass carbon may be as a result of immediate death of cells caused by the disruption of essential functions, and changes in population sizes caused by change in viability resulting from the exposure to the metal. ${ }^{33}$ Cervantes, ${ }^{24}$ suggested additional energy cost to soil microbes as the reason for reduced soil microbial biomass under heavy metals stress conditions, and such additional cost can result in a decrease in the amount of substrate that is available for growth. The decrease in microbial biomass carbon as observed from the beginning to the sixth week of 
the incubation with $\mathrm{Pb}$ and $\mathrm{Cd}$ may also be due to decline in the size of soil microbial community and a reduction of carbon mineralization in these soils. ${ }^{25}$ The later rise in microbial biomass carbon at the eight week may be as a result of development of tolerance and shifts in community structure to compensate for loose of more sensitive populations ${ }^{26,27}$

\section{Conclusion}

The research carried out revealed that concentration and time of exposure of $\mathrm{Pb}$ and $\mathrm{Cd}$ had a significant $(\mathrm{P}<0.05)$ effect on soil microbial biomass carbon. There was a significant decrease in the microbial biomass carbon for all treated soils from the second week to the sixth week, and an increase in microbial biomass carbon was observed on the eight week. At the sixth week, $2000 \mathrm{mgkg}^{-1} \mathrm{~Pb}$ and

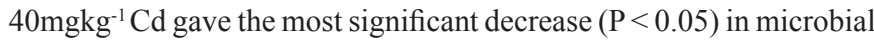
biomass carbon of $98 \%$. Since concentration and time of exposure of heavy metals had an effect on the microbial soil carbon, it invariably means they have an effect on the productivity of soils.

\section{Acknowledgments}

The authors acknowledge the financial support of Mr Emmanuel Oijagbe, the technical support of the staff of Biological Science department of Ahmadu Bello University, Zaria and Mr Jatau Bawa (a staff at the Institute for Agricultural Research, ABU, Zaria) for his technical support.

\section{Conflicts of interest}

Author declares there is no conflicts of interest.

\section{References}

1. Holleman AF, Wiberg E. Lehrbuch der anorganischen chemie. Walter de Gruyter: Berlin; 1985. p. 868.

2. Tchounwou PB, Yedjou CG, Patlolla AK, et al. Heavy Metals Toxicity and the Environment. Exp Suppl. 2012;101:133-64.

3. Saunders J E, Jastrzembski BG, Buckey JC, et al. Hearing loss and heavy metal toxicity in a nicaraguan mining community: audiological results and case reports. Audiology Neurotology. 2013;18(2):101-113.

4. Abolude FO, Adesoji H. Characterization of heavy metal pollution around processing factory using Atomic Absorption Spectrophotometer. Research Journal of Applied Sciences. 2006;1(1-4):16-18.

5. Wintz HT, Fox Vole: Functional genomics and gene regulation in biometals research. Biochemical Society Transactions. 2012;30:766768.

6. Mildvan AS. 9 Metals in Enzyme Catalsis. The enzymes. 1970;2:445536.

7. Sharma RK, Agrawal M. Biological effects of heavy metals: An overview. J Environ Biol. 2005;26(2 Suppl):301-313.

8. Pate JS, Verboom WH. Contemporary biogenic formation of clay pavements by eucalypts: further support for the phytotarium concept. Ann Bot. 2009;103(5):673-685.

9. Raven JA, Edwards D. Roots: evolutionary origins and biogeochemical significance. $J$ Exp Bot. 2001;52(1):381-401.
10. Brookes PC. The use of microbiological parameters in monitoring soil pollution by heavy metals. Biology and Fertility of Soils. 1995;19(4):269-279.

11. Nwuche CO, Ugoji EO. Effects of heavy metal pollution on the soilmicrobial activity. International Journal of Environmental Science and Techology. 2008;5(3):409-414.

12. Wyszkowska J, Wyszkowski M. Effect of cadmium and magnesium on microbiological activity in soil. Polish Journal Environmental Studies. 2002;11(5):585-591.

13. Ghorbani NR, Salehrastin N, Moeini A. Heavy metals affect the microbial populations and their activities. Proc 17th World Congress of Soil Science. 2002;2234:1-11.

14. Ezealor AU, Ebere AP. Seasonal abundance and Diversity of Terrestrial Macro-Invertebrates in Ahmadu Bello University Botanical Garden, Nigeria: Zaria; 2004.

15. Tanko D, Halima Y. Diversity of animal and plant species in the Botanical Garden of Ahmadu Bello University, Nigeria: Zaria; 2012.

16. Walkley A, Black IA. An examination of the Degtjareff method for determining soil organic matter, and a proposed modification of the chromic acid titration method. Soil Science. 37:29-38.

17. Bouyoucos GJ. A recalibration of the hydrometer method for making mechanical analysis of soils. Agronomy journal. 1951;43(9):434-438.

18. Vance ED, Brookes PC, Jenkinson DS. An extraction method for measuring soil microbial biomass. Soil Biology and Biochemistry. 1987;19(6):703-707.

19. Giller KE, Witter E, Mcgrath SP. Toxicity of heavy metals to microorganisms and microbial processes in agricultural soils: A review. Soil Biol Biochem. 1998;30(10):1389-1414.

20. Akmal M, Jianming X. Microbial biomass and bacterial community changes by $\mathrm{Pb}$ contamination in acidic soil. Journal of Agricultural and Biological Sciences, 2009;1:30-37.

21. Chander K, Ulrich E, Jörgensen RG, et al. Decomposition of $14 \mathrm{C}$ labelled wheat straw in repeatedly fumigated and non-fumigated soils with different levels of heavy metal contamination. Biology and Fertility of Soils. 2002;35(2):86-91.

22. Sethi S, Gupta S. Optimization Of Cultural Parameters For Cellulase Enzyme Production From Fungi. Biolife J. 2014;2(3):989-996.

23. Giller KE, Witter E, Mcgrath SP. Toxicity of heavy metals to microorganisms and microbial processes in agricultural soils: A review. Soil Biology and Biochemistry. 1998;30(10):1389-1414.

24. Cervantes C. Copper resistance mechanism in bacteria and fungi. FEMS microbiology Reviews. 1994;14(2):37.

25. Shang H, Yang Q, Wei S, et al. The effects of Mercury and Lead on microbial biomass of paddy soils from South-West China. Procedia Environment Science. 2012;12:468-473.

26. Frossard R. Contaminant uptake by plants. In: Soil Monitoring. Birkhäuser Verlag, Basel. 1993; 7-24.

27. Frostegard A, Baath E. The use of phospholipids fatty acid analysis to estimate bacterial and fungal biomass in soil. Biology and Fertility of Soils. 1996;22(1-2):59-65. 